Brit. J. industr. Med., 1960, 17, 1.

\title{
A CLINICAL AND ENVIRONMENTAL STUDY OF BYSSINOSIS IN THE LANCASHIRE COTTON INDUSTRY
}

\author{
BY
}

\author{
S. A. ROACH and R. S. F. SCHILLING \\ From the Occupational Health Unit, the London School of Hygiene and Tropical Medicine
}

(RECEIVED FOR PUBLICATION DECEMBER 4, 1959)

\begin{abstract}
The prevalence of byssinosis was measured in a population of 189 male and 780 female workers employed in three coarse and two fine cotton mills. Ninety-eight per cent. of the male and $96 \%$ of the female population were seen.

The workers were graded by their histories as follows:-

Grade 0 - No symptoms of chest tightness or breathlessness on Mondays

Grade $\frac{1}{2}$-Occasional chest tightness on Mondays, or mild symptoms such as irritation of the respiratory tract on Mondays

Grade 1-Chest tightness and/or breathlessness on Mondays only

Grade 2-Chest tightness and/or breathlessness on Mondays and other days

The dust concentrations to which the workers were exposed were measured with a dust-sampling instrument based on the hexhlet. Altogether 505 working places were sampled. In the card-rooms of the coarse mills $63 \%$ of the men and $48 \%$ of the women had symptoms of byssinosis. In the card-rooms of the fine mills the corresponding prevalences were $7 \%$ for the men, and $6 \%$ for the women. Prevalences were low in the spinning-rooms in the coarse mills. The mean dust concentrations in the different rooms ranged from $90 \mathrm{mg} . / 100 \mathrm{~m}^{3}$ in one section of the card-room in a fine mill, to $440 \mathrm{mg} . / 100 \mathrm{~m}^{3}$ in one of the card-rooms of the coarse spinning mills. The prevalence of byssinosis in the different rooms was closely related to the overall dustiness $(r=0.93)$. For the three main constituents of the dust, namely, cellulose, protein, and ash, the prevalence of byssinosis correlated most highly with protein, particularly with the protein in the medium-sized dust particles, i.e., approximately 7 microns to $2 \mathrm{~mm}$.

The symptoms of byssinosis may be caused by something in the plant débris which affects the respiratory tract above the level of the terminal bronchioles. This is the site where the mediumsized dust deposits. The possible importance of the fine dust is discussed.

For routine measurements in industry, it is necessary to have a method of assessing dustiness in which the sampling equipment is simple and assessment rapid. As total dust concentration is relatively easy to measure, and correlates closely with the prevalence of byssinosis, permissible levels of dustiness have been expressed in terms of total dust. On comparing the prevalence of byssinosis among workers with short and long exposures and low and high concentrations (Table 11), it appears that a mill with a concentration of $100 \mathrm{mg} . / 100 \mathrm{~m} .^{3}$ or less would be reasonably safe, but in dusty card-rooms it seems that such levels are not possible to achieve at present. As it is necessary to adopt a realistic target that can be achieved, it is suggested that dust concentrations in cotton mills should be less than $250 \mathrm{mg} . / 100 \mathrm{~m} .{ }^{3}$ and that periodic medical examinations should be adopted to protect susceptible workers who can be advised to leave their dusty environment before they are permanently disabled.
\end{abstract}

For more than a century, byssinosis has been known to occur in Lancashire cotton mills (Kay, 1831). It has also been found in other industries in which vegetable fibres are processed, namely, flax and hemp (Werner, 1955) but apparently not in jute (Schilling, 1956).
In the Lancashire cotton industry, byssinosis is more prevalent in mills spinning coarse cotton than in mills spinning fine cotton; and in the card-rooms the prevalence is highest amongst those working near the carding engines (Schilling, 1956).

Byssinosis is caused by the dust produced when 
the cotton is cleaned and prepared for spinning in the mixing, blow, and card-rooms. In the mixingroom, bales of cotton are opened. In the blowroom, dust and short fibres are beaten and blown out of the cotton. In the card-room, the fibres are combed by the carding engine, which process also removes dirt and defective material. The fibres are gathered and twisted into a thin strand or sliver which is drawn out on other machines into a finer strand ready for spinning. The spinning-rooms are less dusty than the other rooms. Nevertheless, some spinning-room workers do have byssinosis although it is usually mild (Schilling, Hughes, Dingwall-Fordyce, and Gilson, 1955). The airborne dust consists of particles ranging in size from fibres up to $1 \frac{1}{2}$ in. long down to particles smaller than $\mathbf{0 \cdot 2}$ microns in diameter. The dust is a mixture of broken cotton fibres, plant débris, minerals, bacteria, and fungi (Drummond, Hamlin, Donoghue, and Brownsett, 1954). Also the differences in the prevalence of byssinosis suggested that there is more airborne dust in mills spinning coarse than in mills spinning fine cotton. Therefore we decided to measure the prevalence of disease and dust conditions in the card-rooms and adjacent processes of a group of coarse and fine cotton mills.

The main object was to determine safe levels of dustiness in the atmosphere and to give the cotton industry a target for dust prevention. It was hoped that this study might also help to identify the causal agent and to determine the size range of the particles causing the disease.

\section{Methods}

Clinical Diagnosis.-In byssinosis there are no specific radiographic or clinical signs (Schilling et al., 1955). The workman notices a tightness of his chest on Mondays or on the first day at work after an absence. If he leaves the industry at this stage, symptoms cease. If he stays, the symptoms persist and chest tightness and breathlessness may extend to other working days until eventually he becomes severely and permanently disabled. The clinical history was used to estimate the prevalence of byssinosis. It has been found that this method of diagnosis is reliable (Schilling, 1956).

The occupational history was recorded and detailed questions were asked about complaints of cough, chest tightness, and breathlessness. In the present study the workers were graded by their histories as follows:-

Grade 0-No symptoms of chest tightness or breathlessness on Mondays

Grade $\frac{1}{2}$-Occasional chest tightness on Mondays, or mild symptoms such as irritation of the respiratory tract on Mondays

Grade 1 -Chest tightness and/or breathlessness on Mondays only

Grade 2-Chest tightness and/or breathlessness on Mondays and other days.

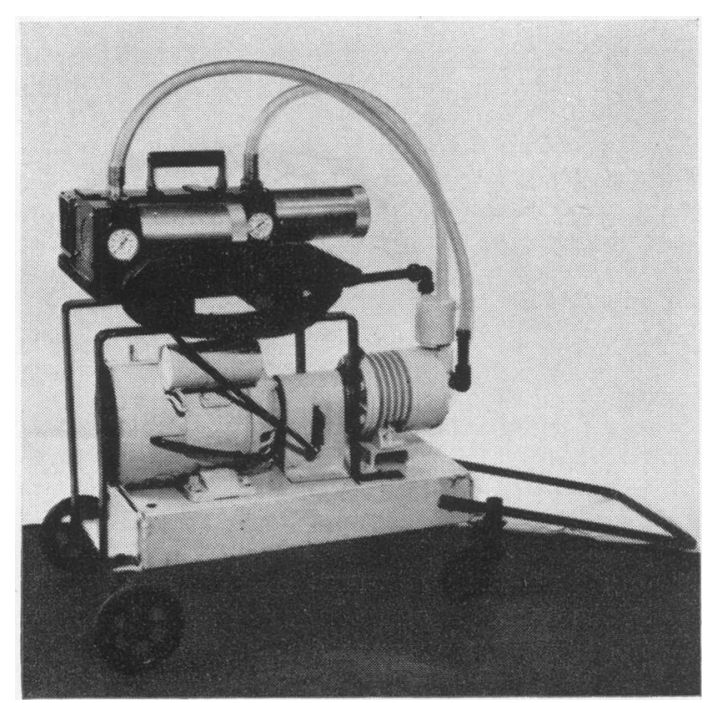

FIG. 1.-The dust sampling machine.

Dr. I. T. T. Higgins, of the Pneumoconiosis Research Unit, and Dr. J. P. W. Hughes, late of the Department of Occupational Health, Manchester University, helped with the clinical survey.

Dust Measurement and Analysis.-It was decided to measure the concentration of airborne dust particles of sizes likely to deposit in the bronchi, because the clinical history of byssinosis suggests that the bronchi are affected. It was also decided to separate the long fibres of cotton floating in the air from the rest of the dust during the sampling because they were unlikely to penetrate very far into the respiratory tract. Since it has been assumed that the finest particles which deposit in the alveoli are responsible for byssinosis (Middleton, 1932; Prausnitz, 1936; Ministry of Labour and National Service, 1952; Schilling, 1956), the concentration of this very fine dust was also measured.

The dust was analysed to derive indices of the concentration of the three main parts of the dust, namely, (1) cellulose, from broken cotton fibres and cotton plants; (2) protein, from the pods, seeds, leaves, and twigs of the cotton plant, and (3) minerals, derived mainly from the soil in which the cotton grows.

The apparatus used (Fig. 1) to measure dust concentration is based upon the hexhlet described by Wright (1954). Air is drawn at a constant flow rate through a filter paper. The suction is provided by a vacuum pump driven by an electric motor and the flow rate is controlled with a critical orifice. The filter papers used were low-resistance, high-efficiency Tullis Russell discs, $7 \mathrm{~cm}$. diameter, weighing about $0.3 \mathrm{~g}$. The flow rate used was $100 \mathrm{l} . / \mathrm{m}$. and each run lasted a shift (eight to nine hours). The filter paper is dried and weighed before and after each sample is taken. The difference in weight gives the weight of dust collected.

A hexhlet normally has a horizontal elutriator at the inlet end. Each apparatus had two hexhlets running in 
parallel, in one of which the horizontal elutriator is removed and replaced by a $7 \mathrm{~cm}$. diameter wire gauze with square holes $2 \mathrm{~mm}$. $\times 2 \mathrm{~mm}$. In the hexhlet with the elutriator, only fine dust is collected.

The size, density, and shape of dust particles determines their dynamic behaviour when suspended in air and how deep into the lung they penetrate before depositing. These properties also determine their speed of settling under gravity in a similar way.

The elutriator of a hexhlet is designed to separate the coarse particles from the air passing through it so that only the fine particles which would reach the alveoli and terminal bronchioles collect on the filter paper.

The elutriator consists of a bank of parallel plates of which the total floor area is such that $50 \%$ of the particles with an equivalent diameter of 5 microns deposit on the plates and $50 \%$ pass on. The "equivalent" diameter of a particle is equal to the diameter of a unit density sphere of which the falling velocity is equal to that of the particle. Most of the particles smaller than 5 microns pass through the elutriator and most larger particles deposit on the plates. The proportion of particles passing the elutriator decreases with increasing equivalent diameter. Particles larger than $7 \cdot 1$ microns equivalent diameter do not pass through (see Fig. 2). The dust deposited on the plates is rejected.

In the hexhlet with the wire gauze replacing the elutriator, the dust collected consists of particles with dimensions up to $2 \mathrm{~mm}$. Long fibres collect on the outside of the gauze. These are wiped off periodically during each run and subsequently weighed and analysed. This dust we call "coarse" dust. The dust which penetrates the gauze we call "medium and fine" dust and the dust which penetrates the elutriator we call "fine" dust. Thus the amount of "medium" dust is obtained by difference.

The filter papers with dust on them were cut in half and one half was used to estimate the amount of protein and the other half to estimate the amount of mineral. The remainder was assumed to consist mostly of cellulose from the cotton fibres and plant débris. The protein was estimated by determining the amount of organic nitrogenous material with a micro-Kjeldahl apparatus.

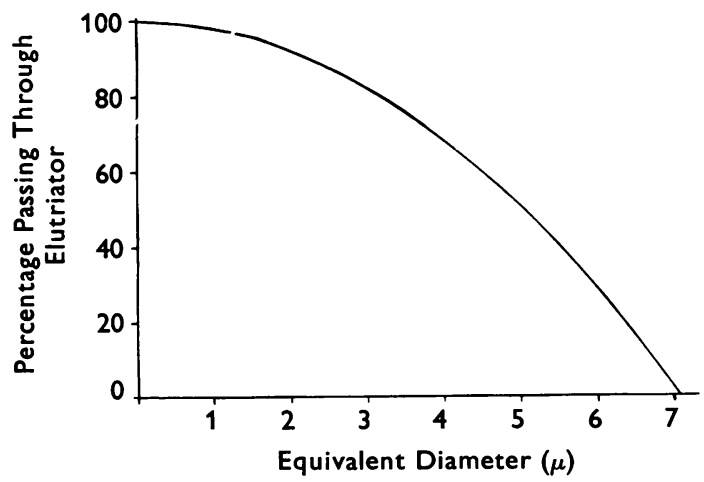

FIG. 2.-Curve denoting the proportion of particles of different sizes passing through the horizontal elutriator of a hexhlet.
The mineral content was estimated by ashing the sample and weighing the ash. Most of the samples were weighed and analysed in the chemistry department of the Pneumoconiosis Research Unit under Dr. T. G. Morris. This analysis of the dust into three components is essentially the same as that described by Silverman and Viles (1950).

\section{Mills Studied}

Two groups of mills in Lancashire were included in this study. Their conditions had not changed substantially for 25 years and they were believed to be dusty. In one there were three mills, spinning low-grade coarse cotton from the U.S.A. and Nigeria, and in the other there were two mills, spinning high-grade fine cotton from Sea Island and the Sudan.

Populations.-The clinical studies of the workers in the card, blow, and mixing-rooms were made in the summer and autumn of 1955 . The spinning-room operatives of the coarse mills were examined in the autumn of 1956.

The population studied was all those working in these rooms at the start of the survey. Those under the age of 25 working in the spinning-rooms were not examined. Ninety-eight per cent. of the men and $96 \%$ of the women in the defined population were seen. No one refused (Table 1).

TABLE 1

POPULATIONS IN THE MILLS

\begin{tabular}{l|c|c|c|c}
\hline & \multicolumn{2}{|c|}{ Coarse Mills } & Fine Mills & \\
\cline { 1 - 3 } & $\begin{array}{c}\text { Card- } \\
\text { Blow- } \\
\text { and } \\
\text { Mixing-room } \\
\text { Workers }\end{array}$ & $\begin{array}{c}\text { Spinning- } \\
\text { room } \\
\text { Workers }\end{array}$ & $\begin{array}{c}\text { Card- } \\
\text { Blow- } \\
\text { and } \\
\text { Mixing-room } \\
\text { Workers }\end{array}$ & Total \\
\cline { 1 - 1 } & 73 & 50 & 62 & $\begin{array}{c}195 \\
(98 \%) \\
2\end{array}$ \\
$\begin{array}{l}\text { Meen and graded } \\
\text { Away sick } \\
\text { Left during survey }\end{array}$ & 2 & 1 & 1 & 2 \\
\hline$\quad$ Total & 75 & 51 & 63 & 189 \\
\hline $\begin{array}{l}\text { Women } \\
\text { Seen and graded }\end{array}$ & 231 & 355 & 163 & $\begin{array}{c}749 \\
(96 \%) \\
13\end{array}$ \\
$\begin{array}{l}\text { Away sick } \\
\text { Left during survey }\end{array}$ & 11 & 8 & 4 & 5 \\
\hline \multicolumn{1}{c|}{ Total } & 243 & 365 & 172 & 780 \\
\hline
\end{tabular}

Airborne Dust.-The dust samples were taken between 1955 and 1957. To measure the dust exposure of the workers a list of names of those in each room was first obtained. These names were placed in random order and samples were taken successively alongside these workers until about 50 working places in each main

TABLE 2

PLACES SAMPLED FOR DUST

\begin{tabular}{c|c|c|c|c}
\hline & \multicolumn{2}{|c|}{ Coarse Mills } & Fine Mills & Total \\
\cline { 2 - 5 } & $\begin{array}{c}\text { Card- } \\
\text { Blow- } \\
\text { and } \\
\text { Mixing-rooms }\end{array}$ & $\begin{array}{c}\text { Spinning- } \\
\text { rooms }\end{array}$ & $\begin{array}{c}\text { Card- } \\
\text { rooms }\end{array}$ & Tom \\
\cline { 1 - 3 } $\begin{array}{c}\text { No. of working } \\
\text { places sampled }\end{array}$ & 205 & 191 & 109 & 505 \\
\hline
\end{tabular}


room had been covered (see Oldham and Roach, 1952). Each sample lasted a shift and the instrument was left at the working place all day. It was put as near to the worker as possible without interfering with his work. Normally, three samples were obtained each day: a sample of fine dust, of fine and medium dust together, and of coarse dust. Samples were taken at 505 working places (Table 2).

The sampling machines were attended by mill overlookers who were given detailed instructions about where and when to take the samples. Checks were made from time to time to ensure that this was done correctly.

\section{Results}

Prevalence of Byssinosis. - In the coarse mills, the prevalence of byssinosis was high in the card-room workers $(51 \%)$ and low in the spinners $(2 \%)$ (Table 3). In the mixing- and blow-room workers, of whom there were $27,11(41 \%)$ had byssinosis.

In the fine mills the prevalence of byssinosis was low in the card-room workers $(6 \%)$ and none of the eight mixing- and blow-room workers had byssinosis.

Within the card-rooms, the nearer workers were to the carding engines the higher was the prevalence of disease (Table 4).

Schilling (1956) found similar trends in a survey of card-room workers in coarse and fine mills.

Dust Concentrations.-There was a wide range of dust concentrations in all the workrooms; but generally the concentrations were higher in the coarse than in the fine mills and higher near the carding engines than in other positions in the cardroom (Table 5).

Monday Symptoms and Dust Concentrations.-In Table 6 we give a summary of the dust sampling results in card-rooms on different days of the week. The mean concentration of dust was lower on Mondays than on other days. Drummond et al. (1954) also found that the concentration of airborne

TABLE 3

PREVALENCE OF BYSSINOSIS

\begin{tabular}{|c|c|c|c|c|c|c|c|c|c|c|c|c|c|c|c|}
\hline & \multicolumn{10}{|c|}{ Coarse Mills } & \multirow{2}{*}{\multicolumn{5}{|c|}{$\begin{array}{c}\text { Fine Mills } \\
\text { Card-rooms }\end{array}$}} \\
\hline & \multicolumn{5}{|c|}{ Card-rooms } & \multicolumn{5}{|c|}{ Spinning rooms } & & & & & \\
\hline & \multirow{3}{*}{$\begin{array}{l}\text { No. of } \\
\text { Workers }\end{array}$} & \multirow{2}{*}{\multicolumn{3}{|c|}{$\begin{array}{c}\begin{array}{c}\text { No. with } \\
\text { Byssinosis }\end{array} \\
\text { Grades }\end{array}$}} & \multirow{3}{*}{ Total } & \multirow{3}{*}{$\begin{array}{l}\text { No. of } \\
\text { Workers }\end{array}$} & \multirow{2}{*}{\multicolumn{3}{|c|}{$\begin{array}{c}\begin{array}{c}\text { No. with } \\
\text { Byssinosis }\end{array} \\
\text { Grades }\end{array}$}} & \multirow{3}{*}{ Total } & \multirow{3}{*}{$\begin{array}{l}\text { No. of } \\
\text { Workers }\end{array}$} & \multirow{2}{*}{\multicolumn{3}{|c|}{$\begin{array}{c}\begin{array}{c}\text { No. with } \\
\text { Byssinosis }\end{array} \\
\text { Grades }\end{array}$}} & \multirow{3}{*}{ Total } \\
\hline & & & & & & & & & & & & & & & \\
\hline & & $\frac{1}{2}$ & 1 & 2 & & & $\frac{1}{2}$ & 1 & 2 & & & $\frac{1}{2}$ & 1 & 2 & \\
\hline $\begin{array}{l}\text { Men } \\
\text { Women }\end{array}$ & $\begin{array}{r}52 \\
225\end{array}$ & $\begin{array}{c}4 \\
25\end{array}$ & $\begin{array}{l}19 \\
65\end{array}$ & $\begin{array}{l}10 \\
19\end{array}$ & $\begin{array}{r}33(63 \%) \\
109(48 \%)\end{array}$ & $\begin{array}{r}50 \\
355\end{array}$ & $\begin{array}{l}2 \\
2\end{array}$ & $\begin{array}{l}3 \\
2\end{array}$ & $\begin{array}{l}\mathbf{0} \\
\mathbf{0}\end{array}$ & $\begin{array}{l}5(11 \%) \\
4(1 \%)\end{array}$ & $\begin{array}{r}56 \\
161\end{array}$ & $\begin{array}{l}1 \\
\mathbf{3}\end{array}$ & $\begin{array}{l}2 \\
4\end{array}$ & $\begin{array}{l}1 \\
2\end{array}$ & $\begin{array}{l}4(7 \%) \\
9(6 \%)\end{array}$ \\
\hline
\end{tabular}

TABLE 4

PREVALENCE OF BYSSINOSIS IN CARD- AND SPINNINGROOMS

\begin{tabular}{l|c|c|c|c}
\hline \multicolumn{1}{c|}{$\begin{array}{c}\text { Place of } \\
\text { Work* }\end{array}$} & \multicolumn{2}{|c|}{ Coarse Mills } & \multicolumn{2}{c|}{ Fine Mills } \\
\cline { 2 - 3 } & $\begin{array}{c}\text { No. of } \\
\text { Workers }\end{array}$ & $\begin{array}{c}\text { No. with } \\
\text { Byssinosis }\end{array}$ & $\begin{array}{c}\text { No. of } \\
\text { Workers }\end{array}$ & $\begin{array}{c}\text { No. with } \\
\text { Byssinosis }\end{array}$ \\
\hline $\begin{array}{c}\text { At or near carding } \\
\text { engines }\end{array}$ & 123 & $77(63 \%)$ & 32 & $7(22 \%)$ \\
$\begin{array}{c}\text { Elsewhere in card- } \\
\text { room }\end{array}$ & $\begin{array}{c}96 \\
\text { Spinning-rooms }\end{array}$ & $\begin{array}{c}43(45 \%) \\
9(2 \%)\end{array}$ & 175 & $6(3 \%)$ \\
\hline
\end{tabular}

*Those who worked in more than one place have been excluded from this table.
TABLE 6

MEAN CONCENTRATION OF DUST IN CARD-ROOMS ON DIFFERENT DAYS OF THE WEEK

\begin{tabular}{l|c|c}
\hline \multicolumn{1}{c|}{ Day of Week } & $\begin{array}{c}\text { Total Dust } \\
\text { (Mean Concentration } \\
\text { mg. per 100 m. }\end{array}$ & No. of Samples* \\
\hline Monday & 331 & 34 \\
Tuesday & 360 & 36 \\
Wednesday & 368 & 32 \\
Thursday & 397 & 37 \\
Friday & 360 & 32 \\
\hline
\end{tabular}

*Including all total dust samples obtained in card-rooms of coarse mills and around carding engines in fine mills. 
dust on Mondays was no higher than on other days. Thus, it appears that the characteristic Monday symptoms of byssinosis are not due to higher dust exposures on this day.

Size Distribution and Chemical Analysis of the Dust.-The size distribution of the dust is summarized in Table 7.

TABLE 7

SIZE DISTRIBUTION OF THE DUST

\begin{tabular}{|c|c|c|c|c|}
\hline \multirow[b]{2}{*}{ Type of Mill } & \multirow[b]{2}{*}{ Room } & \multicolumn{3}{|c|}{ Percentage by Weight in Size Range } \\
\hline & & $\begin{array}{c}\text { *Fine } \\
(<\text { than } \\
7 \text { microns })\end{array}$ & $\begin{array}{l}\text { *Medium } \\
(7 \mathrm{microns} \\
\text { to } 2 \mathrm{~mm} \text {.) }\end{array}$ & $\begin{array}{l}{ }^{*} \text { Coarse } \\
\text { (> than } \\
2 \mathrm{~mm} .)\end{array}$ \\
\hline Coarse & $\begin{array}{l}\text { Card } \\
\text { Spinning }\end{array}$ & $\begin{array}{l}7 \\
6\end{array}$ & $\begin{array}{l}30 \\
10\end{array}$ & $\begin{array}{l}63 \\
84 \\
\end{array}$ \\
\hline Fine & Card & 5 & 34 & 60 \\
\hline
\end{tabular}

* See section on dust measurement and analysis for detailed definition.

In all the rooms, less than $8 \%$ by weight of the dust consisted of fine particles. The coarse dust, which collects on the outside of the gauze, accounted for $60 \%$ or more of the dust.

A summary of the chemical analysis of the dust is given in Table 8 . In all rooms the coarse dust contained $85 \%$ or more cellulose. This was expected, since it is mainly cotton fibres. On the other hand, the medium and fine dust had much higher proportions of protein and minerals.

TABLE 8

CHEMICAL ANALYSIS OF DUST

\begin{tabular}{|c|c|c|c|c|c|}
\hline \multirow{2}{*}{$\begin{array}{l}\text { Type } \\
\text { of } \\
\text { Mill }\end{array}$} & \multirow{2}{*}{ Room } & \multirow{2}{*}{ Size of Dust } & \multicolumn{3}{|c|}{ Proportion by Weight (\%) } \\
\hline & & & Cellulose & Protein & Minerals \\
\hline \multirow{2}{*}{ Coarse } & Card & $\begin{array}{l}\text { Fine } \\
\text { Medium } \\
\text { Coarse }\end{array}$ & $\begin{array}{l}45 \\
51 \\
85\end{array}$ & $\begin{array}{r}21 \\
21 \\
8\end{array}$ & $\begin{array}{r}34 \\
28 \\
7\end{array}$ \\
\hline & Spinning & $\begin{array}{l}\text { Fine } \\
\text { Medium } \\
\text { Coarse }\end{array}$ & $\begin{array}{l}27 \\
50 \\
94\end{array}$ & $\begin{array}{r}27 \\
14 \\
3\end{array}$ & $\begin{array}{r}47 \\
36 \\
3\end{array}$ \\
\hline Fine & Card & $\begin{array}{l}\text { Fine } \\
\text { Medium } \\
\text { Coarse }\end{array}$ & $\begin{array}{l}36 \\
53 \\
86\end{array}$ & $\begin{array}{r}21 \\
15 \\
7\end{array}$ & $\begin{array}{r}43 \\
32 \\
7\end{array}$ \\
\hline
\end{tabular}

TABLE 9

PREVALENCE OF BYSSINOSIS IN 10 GROUPS OF WORKROOMS

\begin{tabular}{l|c|l|c|c}
\hline $\begin{array}{c}\text { Type of } \\
\text { Mill }\end{array}$ & $\begin{array}{c}\text { Mill } \\
\text { No. }\end{array}$ & \multicolumn{1}{|c|}{ Workroom(s) } & $\begin{array}{c}\text { No. of } \\
\text { Workers }\end{array}$ & $\begin{array}{c}\text { No. with } \\
\text { Byssinosis }\end{array}$ \\
\hline $\begin{array}{ll}\text { Coarse } \\
\text { Coarse }\end{array}$ & 1 & Top card-room & 14 & $1(7 \%)$ \\
Coarse & 2 & Bottom card-room & 20 & $4(20 \%)$ \\
Coarse & 3 & Both card-rooms & 19 & $17(89 \%)$ \\
Fine & 4 Both card-rooms & 42 & $23(55 \%)$ \\
Fine & 4 Card-rooms & Combing-rooms & 70 & $2(22 \%)$ \\
Fine & $4 \& 5$ & Frame-rooms & 43 & $2(3 \%)$ \\
Coarse & 1 & Both spinning-rooms & 15 & $0(2 \%)$ \\
Coarse & 2 & Both spinning-rooms & 27 & $1(4 \%)$ \\
Coarse & 3 & Both spinning-rooms & 50 & 0 \\
\hline & \multicolumn{1}{|c|}{ Total } & 309 & $51(17 \%)$ \\
\hline
\end{tabular}

2

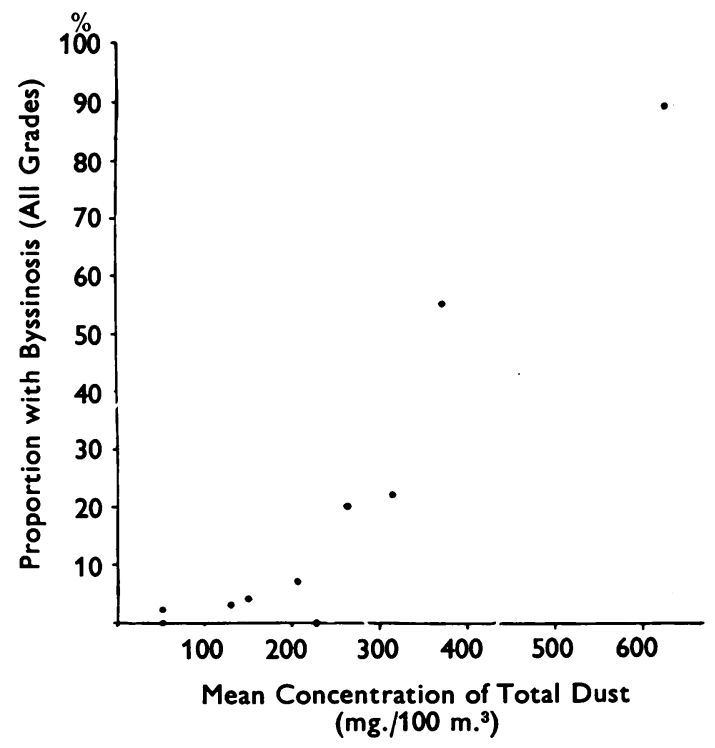

Fig. 3.-Airborne concentration of dust related to prevalence of byssinosis.

Byssinosis and Dust Concentration.-The relationship between prevalence of byssinosis and dust concentration was examined in 10 groups of workers who had spent $95 \%$ or more of their time in one room or pair of similar rooms. The prevalence in these groups is given in Table 9.

The degree of association between the dust concentration and prevalence of byssinosis in these 10 groups can be expressed as a correlation coefficient. The correlation of the concentration of total dust with the prevalence of byssinosis was 0.93 (Fig. 3). The relative importance of different fractions of the dust can be examined by comparing the extent to which their concentrations are correlated with prevalence.

The cotton fibres, which consist mainly of cellulose, are unlikely to be responsible for byssinosis since cellulose is a very stable substance and insoluble in water or other common solvents. However, it may be contributory as a mechanical irritant.

The minerals in the dust, being derived principally from the soil, will consist mainly of silicates and silica. The airborne concentration of the "ash" fraction of the dust lies between $10 \mathrm{mg} . / 100 \mathrm{~m}^{3}$ and $80 \mathrm{mg} . / 100 \mathrm{~m}^{3}{ }^{3}$ In industries where a risk of pneumoconiosis due to mineral dust is present the concentration of dust is usually some 100 times greater than that in these cotton mills. Therefore, it is not likely to be important in byssinosis. This is confirmed by the absence of specific radiological changes in cotton workers. However there may 
be some chemical in the mineral fraction which is contributory at least in part to byssinosis.

The third fraction of the dust, the brittle and dried plant débris other than cotton fibres, is found only in the cotton industry and other industries processing vegetable fibres and will consist of a variety of complex organic compounds, mainly proteins and carbohydrates many of which are easily soluble in water. Of the three major constituents this plant débris would seem by exclusion to be the one most likely to contain or be closely associated with the active constituent.

The correlation of prevalence with the airborne concentration of protein was 0.94 , with cellulose 0.81 and ash 0.58 (Table 10). The correlation of any one of these with prevalence may be due to the particular constituent being responsible for byssinosis, but may also be due to the constituent being closely correlated with one of the other two, which is in turn the responsible agent or closely associated with it. We can compare the degree of association of prevalence with the three constituents and eliminate the effect of any cross correlation by calculating the partial correlations. By this process we estimate the correlation which would have been obtained if the other variables had been constant.

TABLE 10

CORRELATION OF PREVALENCE OF BYSSINOSIS WITH DUST CONCENTRATION

\begin{tabular}{l|c|c}
\hline \multirow{2}{*}{ Concentration of } & \multicolumn{2}{|c}{ Correlation with Prevalence } \\
\cline { 2 - 3 } & Total Correlation & Partial Correlation \\
\hline Total dust & 0.93 & - \\
\hline All cellulose & 0.81 & 0.58 \\
All protein & 0.94 & $\begin{array}{r}0.90 \\
-0.40\end{array}$ \\
All ash & 0.58 & 0.58 \\
\hline Fine protein & 0.95 & 0.03 \\
Medium protein & 0.55 \\
Coarse protein & 0.14 \\
\hline
\end{tabular}

The partial correlation of prevalence with protein when the effects of the cellulose and ash were eliminated was 0.90 . With cellulose it was 0.58 when protein and ash were eliminated and with ash it was -0.40 when protein and cellulose were eliminated. This suggests that the cotton fibres and the minerals are relatively unimportant and that the active agent in the cotton dust is most likely to be closely associated with the protein.

In a similar way we can examine the relative importance of the different size fractions of the protein in producing this close association, by comparing the extent to which they are correlated with prevalence.

The fine fraction of the dust is the size which can penetrate to the terminal bronchioles and alveoli, the medium fraction of the dust is the size which deposits mainly in the trachea, bronchi, and bronchioles, and the coarse fraction is not likely to penetrate past the nose and mouth. The clinical picture of byssinosis suggests that the bronchi and bronchioles are affected. If this is so, then the medium-sized dust is likely to be the most important size range. The fine dust may also be important as much of it deposits before reaching the alveoli and that which does reach the alveoli may produce a reaction there. When collecting the coarse fraction of the dust it is trapped by the wire gauze at the entrance to the sampler. Some of the medium and fine dust is filtered out by this coarse dust before it is picked off, so that the coarse fraction may contain some of the material which if inhaled would normally penetrate into the bronchi, bronchioles, and alveoli. Because of this the recorded concentration of coarse dust may be found to be associated with prevalance.

The total correlation of prevalence with the airborne concentration of fine protein was $0 \cdot 58$, with medium protein 0.95 , and with coarse protein was 0.93 .

The partial correlation of prevalence with fine protein, after eliminating medium and coarse protein was 0.03 , the partial correlation with medium protein was 0.55 after eliminating fine and coarse protein, and with coarse protein was 0.14 after eliminating fine and medium protein.

The statistical significance of these correlation coefficients is difficult to judge since the variates are not distributed normally (see Fig. 3, Table 10). However, the results suggest that the prevalence of byssinosis was more highly associated with the concentration of medium protein than with the concentration of the other constituents and that the total correlation of prevalence with the other constituents may be largely accounted for by their association with this fraction.

It should be emphasized that this does not in any way prove that byssinosis is caused by the protein in the medium-sized dust. The link, if it exists, may be an indirect one. Also, larger errors in estimating the other constituents may have produced the lower correlations. For example, it is certainly more difficult to determine the concentration of fine protein than medium protein due to the much smaller quantities available for analysis and the difficulty of separating the fine dust during collection.

Permissible Levels of Dustiness.-For routine measurements of dust it is necessary to have a method in which the sampling equipment is simple and the assessment of the samples is rapid. As total dust concentration is easy to measure and 
TABLE 11

PROPORTION OF WORKERS* WITH BYSSINOSIS GROUPED BY DURATION OF EXPOSURE AND CONCENTRATION OF DUST

(Byssinosis Grades 1 and 2 only)

\begin{tabular}{|c|c|c|c|c|c|c|c|c|c|c|c|c|}
\hline $\begin{array}{l}\text { Duration } \\
\text { of } \\
\text { Exposure }\end{array}$ & \multicolumn{12}{|c|}{ Concentration of Dust (mg./100 m. ${ }^{3}$ ) } \\
\hline & \multicolumn{2}{|c|}{ o- } & \multicolumn{2}{|c|}{$100-$} & \multicolumn{2}{|c|}{$175-$} & \multicolumn{2}{|c|}{$250-$} & \multicolumn{2}{|c|}{375} & \multicolumn{2}{|c|}{$500+$} \\
\hline & $\begin{array}{l}\text { No. with } \\
\text { Byssinosis }\end{array}$ & $\begin{array}{l}\text { No. in } \\
\text { Group }\end{array}$ & $\begin{array}{c}\text { No. with } \\
\text { Byssinosis }\end{array}$ & $\begin{array}{l}\text { No. in } \\
\text { Group }\end{array}$ & $\begin{array}{c}\text { No. with } \\
\text { Byssinosis }\end{array}$ & $\begin{array}{l}\text { No. in } \\
\text { Group }\end{array}$ & $\begin{array}{c}\text { No. with } \\
\text { Byssinosis }\end{array}$ & $\begin{array}{l}\text { No. in } \\
\text { Group }\end{array}$ & $\begin{array}{c}\text { No. with } \\
\text { Byssinosis }\end{array}$ & $\begin{array}{l}\text { No. in } \\
\text { Group }\end{array}$ & $\begin{array}{l}\text { No. with } \\
\text { Byssinosis }\end{array}$ & $\begin{array}{l}\text { No. in } \\
\text { Group }\end{array}$ \\
\hline $\begin{array}{r}0= \\
5= \\
10= \\
20= \\
30=\end{array}$ & $\begin{array}{l}\mathbf{0} \\
\mathbf{0} \\
\mathbf{0} \\
\mathbf{0} \\
\mathbf{0}\end{array}$ & $\begin{array}{r}14 \\
17 \\
23 \\
18 \\
9\end{array}$ & $\begin{array}{l}\mathbf{0} \\
0 \\
1 \\
3 \\
2\end{array}$ & $\begin{array}{l}59 \\
20 \\
30 \\
27 \\
24\end{array}$ & $\begin{array}{l}0 \\
2 \\
4 \\
2 \\
3\end{array}$ & $\begin{array}{l}23 \\
14 \\
29 \\
14 \\
10\end{array}$ & $\begin{array}{l}1 \\
4 \\
9 \\
2 \\
2\end{array}$ & $\begin{array}{r}17 \\
11 \\
22 \\
3 \\
6\end{array}$ & $\begin{array}{r}5 \\
3 \\
10 \\
3 \\
1\end{array}$ & $\begin{array}{r}14 \\
6 \\
18 \\
4 \\
2\end{array}$ & $\begin{array}{l}3 \\
4 \\
4 \\
1 \\
0\end{array}$ & $\begin{array}{l}7 \\
7 \\
8 \\
1 \\
1\end{array}$ \\
\hline Total & 0 & 81 & 6 & 160 & 11 & 90 & 18 & 59 & 22 & 44 & 12 & 24 \\
\hline
\end{tabular}

*Excluding those who had worked in coal-mines or who had spent more than $5 \%$ of their period of employment in other cotton mills.

correlates closely with prevalence of byssinosis $(r=0.93)$, our permissible levels of dustiness are expressed in terms of total dust.*

There were 458 workers whose experience lay in environments where the dust concentration had been measured. Their duration of exposure and corresponding average concentration are summarized in Table 11. This gives the number of workers and how many of them had byssinosis grades 1 and 2. Although all these workers had chest tightness, many of them were not permanently disabled. However, it is likely that continual exposure to conditions causing these symptoms would eventually give rise to permanent disability.

Amongst those exposed to an average concentration of more than $250 \mathrm{mg}$. per $100 \mathrm{~m}^{3}$ there was a high proportion $(41 \%)$ with byssinosis. Even when the period of exposure was very short a substantial number were affected. Clearly, dust control is essential in any room as dusty as this.

Amongst workers exposed to concentrations of between 100 and $250 \mathrm{mg}$. per $100 \mathrm{~m}^{3}$, two workers among those with less than 10 years' exposure had byssinosis. Thus, dust control is also desirable where the concentration lies in this range.

None of those workers exposed to a concentration of less than $100 \mathrm{mg}$. per $100 \mathrm{~m}^{3}$ had byssinosis grade 1 or 2 . One man with a long experience did complain of occasional chest tightness on Mondays, so that although a card-room with a concentration of less than $100 \mathrm{mg}$. per $100 \mathrm{~m}^{3}$ would probably be safe, it would be wise to safeguard the particularly sensitive individuals by periodic medical examinations. With higher concentrations, such examinations are essential in order to protect susceptible workers who can be advised to leave their dusty environment before they are permanently disabled.

*The correlation of prevalence with concentration of fine dust was $\mathbf{0} \cdot 10$.
In summary our results suggest the following classification:-

\begin{tabular}{|c|c|}
\hline Grade of Dustiness & Concentratiop Total Dust \\
\hline $\begin{array}{l}\text { A. Safe, with medical supervision } \\
\text { of workers } \\
\text { B. Dust control desirable and medi- } \\
\text { cal supervision essential } \\
\text { C. Dust control and medical super- } \\
\text { vision essential }\end{array}$ & $\begin{array}{l}\text { Less than } 100 \mathrm{mg} . / 100 \mathrm{~m}^{3} \\
\text { Between } 100 \text { and } 250 \mathrm{mg} . / \\
100 \mathrm{~m}^{3} \\
\text { More than } 250 \mathrm{mg} . / 100 \mathrm{~m}^{3}\end{array}$ \\
\hline
\end{tabular}

\section{Discussion}

In byssinosis the clinical symptom of chest tightness on Mondays seems to be a specific response to inhaling the cotton dust and is very unlikely to be caused by mechanical irritation. The relationship between prevalence of byssinosis and the various components of the dust reported in this paper gives further support to this view and points to some constituent of the plant débris as the active agent.

The dust particles of less than 7 microns diameter are apparently less important than the larger particles. The explanation of this may be simply that there is much more dust in the medium and coarse size ranges. In the card-rooms of the coarse mills, in every $100 \mathrm{mg}$. of dust there was about $6 \mathrm{mg}$. of medium protein and $1.5 \mathrm{mg}$. of fine protein. The agent causing byssinosis seems to be associated with this protein and may in fact be part of it. Thus, the amount of the agent in the fine dust is probably considerably less than the corresponding amount in the dust in the medium size range. Furthermore, the sensation of chest tightness may originate in the respiratory tract above the level of the terminal bronchioles, where most of the medium-sized particles will fall. However, it is not possible to rule out the fine dust altogether. It may be affecting the terminal bronchioles or alveoli without necessarily causing the sensation of chest tightness. It is urgently necessary to be sure of the importance or 
otherwise of the fine dust since the fine dust is much more difficult to suppress than is the medium or coarse dust.

Bacteria and moulds have relatively high concentrations in the atmosphere of cotton card-rooms and have been considered as possible causes of byssinosis (Drummond and Hamlin, 1952). In addition, Thiry (1941) has suggested that moulds and bacteria are the causes of the diseases in flax workers. The amount of protein in the dust from bacteria and fungi is very small, but recent work by Tuffnell (personal communication) showed a correlation between prevalence of byssinosis and concentrations of viable organisms of the genus Bacillus. However, when he exposed three men with disabling byssinosis to an inert dust carrying Bacillus pumilus and Aspergillus niger, the most common species of bacteria and fungi found in cotton mills, they had no clinical symptoms and showed no reduction in ventilatory capacity.

Our suggested grading of workrooms according to dustiness was arrived at after consideration of the prevalence in groups exposed to similar concentrations for similar lengths of time We might have deduced permissible levels of dustiness from dose response curves in a similar way to that suggested by Roach (1953). However, we were hesitant to do this because of the possible effects of selection in those groups with the highest prevalence of byssinosis. People with byssinosis are generally aware that the dust affects their breathing and it is likely that they will leave their jobs more readily than those who are not so affected. To this extent the people working in a cotton mill are likely to be a selected population, particularly those groups who work in the dustiest jobs and are in consequence affected most by dust. To deduce permissible levels of dustiness from dose-response relationships we would have had to assume that selection operates in an exactly similar way in all mills or does not operate at all.

The amount of dust in the air of a cotton mill seems to depend on the quality of the cotton processed, the weight of cotton spun per week, and the amount of ventilation in the rooms. The more dirt, trash, and short fibre there is in the cotton the greater is the concentration of airborne dust. Also the higher the throughput of cotton the greater is the concentration of airborne dust. The dustiness is reduced by increasing the amount of general ventilation and by installing localized extraction hoods around the sources of dust. The simplest way of testing the effectiveness of these methods is by measuring the reduction in total dust concentration. However, this may not reflect the reduction in concentration of the active agent very accurately. In such a variable and indefinite situation, dust concentration is bound to be only a rough and ready index of the byssinosis risk. The final test of the efficiency of any dust extractor must be whether or not the workers in the room develop byssinosis.

The Shirley pressure point system, which is a local exhaust ventilation system applied to the dusty points of a carding engine, substantially reduces the dust concentration in card-rooms with beneficial effects on the operatives (McKerrow, McDermott, Gilson, and Schilling, 1958; Ministry of Labour and National Service, 1957). It is planned to make a further study of the effects of installing it in a dusty card-room on airborne dust concentrations and on the clinical symptoms and ventilatory capacities of the workers. Similar tests will also be made in a dusty card-room which has a device for improving its general ventilation by a plenum system. Thus we shall have a good estimate of the value of these devices in preventing byssinosis. Preliminary results indicate that although the Shirley pressure point system and those systems which increase general ventilation each substantially reduce the dust concentrations, they may not at present achieve safe levels in very dusty card-rooms.

At the present time we do not think it would be wise to recommend a target level of dustiness which could not be achieved in practice, for this would be likely to result in little or no action. Our aim would be initially to adopt a realistic target that could be achieved in the immediate future by reasonably practicable measures, namely that dust concentrations in cotton mills should be less than $250 \mathrm{mg}$. per $100 \mathrm{~m}^{3}$

We are grateful to many colleagues for their help in making this investigation, especially Dr. I. T. T. Higgins, Dr. J. P. W. Hughes, Miss I. Dingwall-Fordyce, and Dr. T. G. Morris.

We are specially indebted to the management and workers of the cotton mills. They gave their wholehearted cooperation and without their help these surveys could not have been made.

We would also like to thank the following for help in preparing this paper: Dr. J. C. Gilson, Director of the Medical Research Council's Pneumoconiosis Research Unit, Dr. Douglas Hill, Director of the Shirley Institute, and Professor R. E. Lane of Manchester University.

One of us (R.S.F.S.) received a grant from the Medical Research Council to study byssinosis.

\section{REFERENCES}

Drummond, D. G., and Hamlin, M. (1952) Brit. J. industr. Med. 9, 309, 311 . , Donoghue, J. K., and Brownsett, F. (1954). Ibid., 11, 151 .

Kay, J. P. (1831). New Engl. med. surg. J., 1, 357. McKerrow, C. B., McDermott, M., Gilson, J. C., and Schilling,
R. S. F. (1958). Brit. J. industr. Med., 15, 75. 
Middleton, E. L. (1932). Home Office Report of the Departmental Committee on Dust in Card Rooms in the Cotton Industry. H.M.S.O., London.

Ministry of Labour and National Service (1952). 2nd Interim Report on Dust in Card Rooms. H.M.S.O., London.

(1957). Dust in Card Rooms: 3rd Interim Report of the Joint Advisory Committee of the Cotton Industry. H.M.S.O. London.

Oldham, P. D., and Roach, S. A. (1952). Brit. J. industr. Med., 9, 112.
Prausnitz, C. (1936). Spec. Rep. Ser. med. Res. Coun. (Lond.), No. 212 .

Roach, S. A. (1953). Brit. J. industr. Med., 10, 220.

Schilling, R. S. F. (1956). Lancet, 2, 261.

Hughes, J. P. W., Dingwall-Fordyce, I., and Gilson, J. C. (1955). Brit. J. industr. Med., 12, 217.

Silverman, L., and Viles, F. J. (1950). Textile Res. J., 20, 109.

Thiry, U. (1941). Arch. Mal. prof., 3, 129.

Werner, G. C. H. Arch. Mal. prof 165, 3, 12

Wright, B. M. (1954). Brit. J. industr. Med., 11, 284. 